\title{
Annealing Effect of DC-RF Coupled Co-sputtered Boron-Aluminium Nitride Thin Films
}

\author{
Ong Z. $\mathrm{Y}^{1}$., Shanmugan. $\mathrm{S}^{2 *}$ and Mutharasu $\mathrm{D}^{3}$. \\ Nano Optoelectronics and Research Laboratory, School of Physics, \\ Universiti Sains Malaysia (USM), 11800, Minden, Penang, Malaysia
}

\begin{abstract}
Boron (B) doped Aluminium Nitride (AIN) thin film $((\mathrm{B}, \mathrm{Al}) \mathrm{N})$ was synthesized by $\mathrm{DC}-\mathrm{RF}$ coupled co-sputtering and post processed for three different annealing temperatures. The structural properties was studied by $\mathrm{X}$-ray spectra and observed the mixture of cubic BN and hexagonal AIN when annealed up to $300{ }^{\circ} \mathrm{C}$. Increased crystallite size showed the influence of both B doping as well as annealing temperature on crystallite properties of $(\mathrm{B}, \mathrm{Al}) \mathrm{N}$. Compressive and tensile stress was noticed with all samples and observed high value for cubic $B N$ phase at $300{ }^{\circ} \mathrm{C}$. Dislocation density and strain were also changed by the influence of $\mathrm{B}$ doping at high temperatures $\left(>200{ }^{\circ} \mathrm{C}\right)$. AFM images were showed the rough surface of $B$ doped $A I N$ thin film at $400{ }^{\circ} \mathrm{C}$ than other temperatures. The FESEM images revealed the particle agglomeration during $B$ doping into AIN at high annealing temperatures. Elemental composition analysis by EDS spectra were also evidenced the change in surface structure as the effect of annealing.
\end{abstract}

Keywords-Boron, Aluminium Nitride, Thin film, Co-sputtering, structural parameters, surface properties

\section{INTRODUCTION}

Titanium Aluminium Nitride (AlN) is one among the nitride group of material and attractive in electronic and optoelectronic devices. AlN has a high thermal conductivity $\left(260 \mathrm{Wm}^{-1} \mathrm{~K}^{-1}\right)$, a direct band gap $\left(E_{g}=5.9-6.2 \mathrm{eV}\right)$, high level of hardness $\left(2 \times 10^{3} \mathrm{kgf} / \mathrm{mm}^{2}\right)$, high fusion temperature $(2400$ $\left.{ }^{\circ} \mathrm{C}\right)$ and a high acoustic velocity [1]-[2]. Aluminium nitride has also proven to be a very interesting electronic material in MOS technology. The dielectric properties of AIN put this material in an interesting position when the next generation of gate dielectric is chosen. The optimal performance of developing devices depends directly on the crystallographic and electronic properties of the AlN layer [3]-[4]. AlN structure should depend primarily on the sputter technique, variation of process conditions as well as the doping material, which influence the repeatability of the films properties. In order to alter the properties of AlN, several researcher have tried to improve the properties of AlN by doping an element such as $\mathrm{Cr}$ [5] and Sn [6].

In comparison, AlN has received much less attention, although it is successfully in use as a buffer layer for the growth of GaN. Undoped AlN is highly resistive $\sim \mathrm{R}=5 \times 10^{7}$ $10^{13} \mathrm{~V} / \mathrm{cm}$ and intentional doping appears to be difficult. Many researchers have reported highly oriented AlN thin film with columnar structure using various deposition methods such as chemical vapour deposition [7], reactive sputtering [8], pulsed the laser deposition [9] and reactive molecular beam deposition [10]. Among these methods, reactive sputtering is the most appropriate technique for growing AINmetal ternary compounds because it provides good process control, high homogeneity along large area substrates and ease industrialization. Due to poor film composition as a result of reactive sputtering, a more versatile solution is the cosputtering of two elemental targets under reactive atmospheres; in this case, a good control of the composition homogeneity along the substrate is essential.

In this paper, B thin film was co-sputtered during the deposition of AlN and post processed (annealing) at various temperatures. The annealed samples were tested for their structural parameters such as crystallite size, dislocation density, residual stress and strain etc. by using XRD technique. The influence of B inclusion on surface properties of AIN thin film was also tested using SEM \& AFM and the results are discussed here.

\section{EXPERIMENTAL METHOD}

\subsection{XRD analysis}

$\mathrm{TiO}_{2}(\mathrm{~B}, \mathrm{Al}) \mathrm{N}$ films were coated on $\mathrm{Si}(100)$ substrates (1 $\mathrm{cm} \times 1 \mathrm{~cm}$ ) using DC-RF sputtering system (Edwards make, Model-Auto 500). Si substrates were used because the thermal expansion coefficient of metal nitrides matches well with that of silicon [11]. The coating process was conducted using high pure $\mathrm{Al}$ and $\mathrm{B}$ targets of 3 inch in diameter and $4 \mathrm{~mm}$ in thickness, which were coupled to a DC and a RF power sources respectively. Due to low electrical conductivity of boron, radio frequency was used as a power source for boron target [12].

Native oxide on the silicon substrates were cleaned and removed in a solution of $\mathrm{H}_{2} \mathrm{O} / \mathrm{NH}_{4} \mathrm{OH} / \mathrm{H}_{2} \mathrm{O}_{2}(5: 1: 1$ by volume $)$ at $75{ }^{\circ} \mathrm{C}$ and followed by $5 \% \mathrm{HF}$ dilute solution, and then dipped in solution of $\mathrm{H}_{2} \mathrm{O} / \mathrm{HCl} / \mathrm{H}_{2} \mathrm{O}_{2}(6: 1: 1$ by volume $)$ at $75^{\circ} \mathrm{C}$. Cleaned substrates were dried by blowing $\mathrm{N}_{2}$ gas. After the cleaned Si substrates were loaded, the chamber was pump down into high vacuum state of $4.05 \times 10^{-5}$ mbar with turbo molecular pump backed by a rotary pump. High pure argon (Ar) gas $(99.999 \%)$ and nitrogen $\left(\mathrm{N}_{2}\right)$ gas $(99.999 \%)$ were used as sputtering and reactive gas and flowed into the chamber with gas ratio of $A r 7: N_{2} 13.100 \mathrm{~W}$ DC and 50W RF discharge power were applied with chamber pressure maintained at $9.33 \times 10^{-3}$ mbar. The coating was conducted for 1 hour after pre-sputtering was carried out for 5-10 minutes to remove surface oxidation of targets.

The sputtered (B, Al)N films were subjected to postdeposition annealing in high temperature tube furnace at $200{ }^{\circ} \mathrm{C}, 300{ }^{\circ} \mathrm{C}$ and $400{ }^{\circ} \mathrm{C}$ for 2 hours with a constant $\mathrm{N}_{2}$ gas 
flow of $50 \mathrm{sccm}$. The structural properties of the annealed and non-annealed films were evaluated by using X-ray diffraction (XRD, X'pert-PRO, Philips, Netherlands) technique with scan range between $2 \theta=30^{\circ}$ to $80^{\circ}$. The surface morphology of the films was analysed using field emission scanning electron microscope (FESEM, Nova NanoSEM 450) and atomic force microscope (AFM, Bruker AXS). The composition of the films was investigated by energy dispersive X-ray spectroscopy (EDX)

\section{RESULT AND DISCUSSION}

The $(\mathrm{B}, \mathrm{Al}) \mathrm{N}$ thin film was examined by XRD technique and the observed spectra are given as shown in Fig. 1. It clearly indicates the formation of hexagonal AlN along with cubic BN in as grown and sample annealed at $200-400{ }^{\circ} \mathrm{C}$. It is because of deposition by co-sputtering using $\mathrm{B}$ and $\mathrm{Al}$ target simultaneously. For non-annealed $(\mathrm{B}, \mathrm{Al}) \mathrm{N}$ film, it is observed that the sputtering process support the growth of mixed (100) and (110) orientated hexagonal phase AlN at $33.16^{\circ}$ and $61.83^{\circ}$, both peaks exist at almost the same intensity. Besides that, a low intensity peak of (111) orientated cubic $\mathrm{BN}$ is also found at $43.59^{\circ}$.

As the thin film was annealed at $200{ }^{\circ} \mathrm{C}$ under nitrogen environment for 2 hours, the intensity of (110) oriented phase increases and becomes more prominent than (100) orientated phase. In addition, a new peak of (002) oriented hexagonal AlN peaks became evident at $2 \theta=36.01^{\circ}$. As the annealing temperature increases to $300{ }^{\circ} \mathrm{C}$, it is noticed that the temperature does not support the growth of (002) hexagonal AIN. Interestingly the intensity of (100) orientated phase increases and becomes slightly more dominant over hexagonal (110) orientated phase. At $400{ }^{\circ} \mathrm{C}$ annealing temperature, a drastic decrease can be observed on intensity of both (100) and (110) peaks. . It may due to crystal defects as a result of changing the lattice value in the lattice size of $(B$,

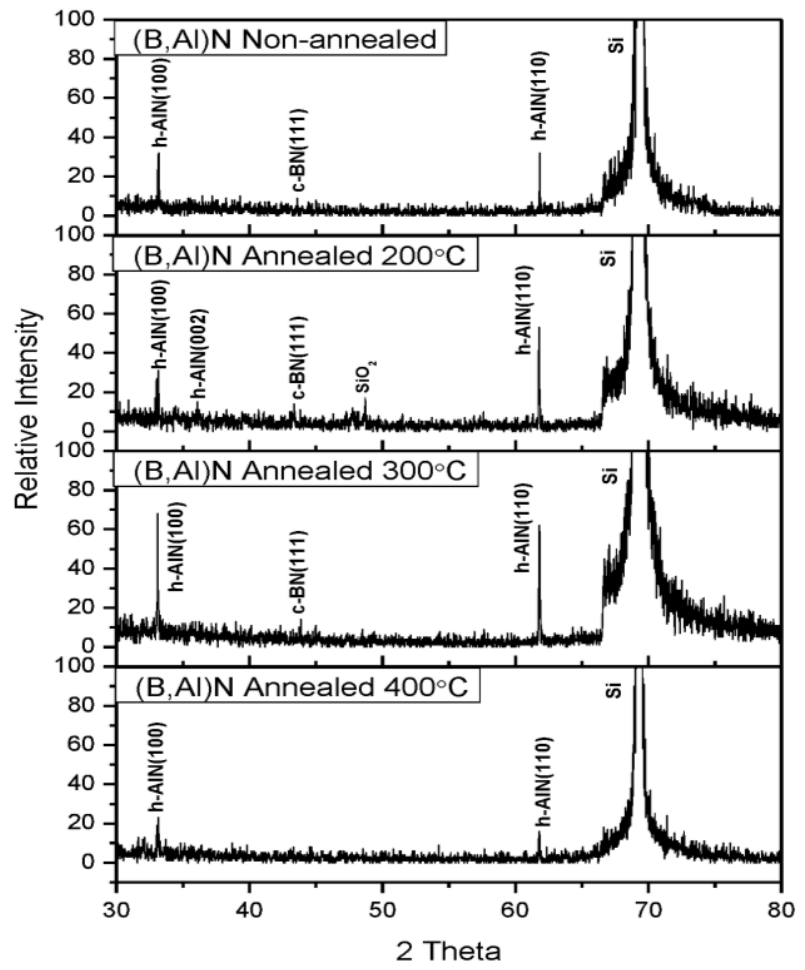

Fig.1. XRD spectra of AlN thin film annealed at various temperature.
$\mathrm{Al}) \mathrm{N}$. The (111) orientated cubic BN peak disappears at this temperature, which may due to the diffusion of B atoms into the AlN structure at high annealing temperature.

Overall the preferred crystal orientation peak of all samples is a mixed phase of (100) and (110) orientated hexagonal AlN. As for BN diffraction peaks, according to J.H. Song et al. [13], the lack of BN peak indicates that it was either amorphous or composed of very small grain sizes. Moreover, the $\mathrm{B}$ atoms are diffused into $\mathrm{AlN}$ to form $(\mathrm{B}, \mathrm{Al}) \mathrm{N}$ during the sputtering process and also further supported by annealing process.

\subsection{Structural Parameter Analysis}

In The crystallite size is calculated based on XRD results by using Debye Scherer formula [14]:

$$
D=0.9 \lambda / \beta \cos \theta
$$

where $\lambda$ is wavelength (in Angstrom), $\beta$ is the broadening of diffraction peak (in radians), $\theta$ is the Bragg diffraction angle. The calculated results are shown in Table I.

From the Table I, the crystallite size of (100) oriented AIN increases when annealed at temperature $200{ }^{\circ} \mathrm{C}$ and $300{ }^{\circ} \mathrm{C}$. However the crystallite size decreases as annealing temperature reach $400{ }^{\circ} \mathrm{C}$, this indicates that the peak width starts to broaden at higher temperature $\left(\geq 400{ }^{\circ} \mathrm{C}\right)$. The peak broadening may probably due to greater structure disorder caused by addition of B to AlN [15]. In contrast, the crystallite size of (110) oriented AlN decreases after annealing process. As for (111) BN, the crystallite size decreases as the annealing temperature increases. The change in crystallite size is also due to the change in cell volume as a result of $\mathrm{B}$ inclusion into AlN lattice. The atomic radius of $\mathrm{B}(8.5 \AA)$ is smaller than that of $\mathrm{Al}(125 \AA)$ and hence the cell contraction is possible while $\mathrm{B}$ doping at high temperature. This will cause the crystallite size reduction of the annealed thin film.

By comparing both calculated crystallite size and FWHM, it is indicated that $(\mathrm{B}, \mathrm{Al}) \mathrm{N}$ film annealed at $200{ }^{\circ} \mathrm{C}$ has the best nanocrystallite structure. There is no significant variation on lattice parameters (c) obtained from XRD measurement as the annealing temperature increases. In the comparison between observed $2 \theta$ and standard $2 \theta$ of (100) AlN peak, the observed $2 \theta$ position of all samples shifted towards lower angles. As for (110) AlN, the peak is shifted towards higher angle. The peak shift may be due to the substitution of smaller $\mathrm{B}$ atoms at $\mathrm{Al}$ positions. From Table I it can be observed that the degree of shifting increases with the rise in annealing temperature. It can be concluded that as the temperature increases in annealing process, the boron atoms are actually incorporated into the crystal

The internal stress $(\sigma)$ in the deposited film is calculated using the relation:

$\sigma=-E\left(d_{a}-d_{o}\right) / 2 d_{o} Y$

Where $d_{o}$ and $d_{a}$ are the $d$ spacing of bulk and thin film forms respectively [16]. E and Y are Young's modulus and Poisson's ratio of AlN are $\mathrm{E}=308 \mathrm{G} \mathrm{Pa}$ [17], $\mathrm{Y}=0.29$ [18], and $\mathrm{BN} \mathrm{E}=748 \mathrm{GPa}$ [19], $\mathrm{Y}=0.19$ [20] respectively.

From (2), the nature of stress applied during the growth of crystal could be identified by the sign of the observed value. Films grown by sputtering technique are known to be quite often stressed, either tensile or compressive stress. If the observed value is positive, it represents the compressive stress, 


\section{International Journal of Engineering Trends and Technology (IJETT) - Volume 17 Number 4 - Nov 2014}

and if it is negative, the tensile stress is applied during the growth process.

From the Table II, it is noticed that the compressive stress is observed for (100) oriented AlN before and after annealing, and also (002) oriented AlN from $200{ }^{\circ} \mathrm{C}$. The compressive stress may be due to the $\mathrm{N}_{2}$ atoms bombardment on the film reflected with high energy from both targets [21]-[22]. In contrast, h-AlN (110) and c-BN (111) exhibit tensile nature in all annealing conditions. The tensile stress is almost constant for h-AlN (110) as annealing temperature increases. At $300{ }^{\circ} \mathrm{C}$, tensile stress of c-BN (111) increases significantly as compare to $200{ }^{\circ} \mathrm{C}$ and non-annealed samples. This significant change in stress is because of the growth of heagonal AlN thin film along with $\mathrm{BN}$ at $300^{\circ} \mathrm{C}$. The bond length between $\mathrm{B}$ and $\mathrm{N}$ is low $(1.33 \AA$ ) when compared with the length between $\mathrm{Al}$ and $\mathrm{N}(1.79 \AA)$. It is expected that the $\mathrm{B}$ may occupy the interstitial position between $\mathrm{Al}$ and $\mathrm{N}$ and hence the bond length will be shorten. This may be the reason for getting the higher tensile stress in crystal when annealed at $300{ }^{\circ} \mathrm{C}$.

In addition to this, dislocation density $(\delta)$, defined as the length of dislocation lines per unit volume of crystal, was evaluated from relation [20]:

$$
\delta=1 / \mathrm{D}^{2}
$$

The dislocation density is mainly based on the crystallite size and hence it differs as a result of change in crystallite size. It is the measure of structural defects. From Table II, it clearly states that the dislocation density varies with the annealing temperatures. For $\mathrm{h}(100)$, the $\delta$ value decreases initially when sample undergoes the annealing process and increases as the temperature increases upto $400{ }^{\circ} \mathrm{C}$. It reveals large crystal defects at this temperature as a result of $\mathrm{B}$ doping to the AlN lattice. For c (111) related to $\mathrm{BN}$ phase, the $\delta$ value increases as the annealing process increases.

The strain $(\varepsilon)$ is calculated from formula:

$\varepsilon=\beta \cos \theta$

The strain value of $\mathrm{h}-\mathrm{AlN}(100)$ from the sputtered $(\mathrm{B}, \mathrm{Al}) \mathrm{N}$ film is 0.00173 and the value decreases as the film is annealed at $200{ }^{\circ} \mathrm{C}$. The value increases as the annealing temperature rises from $200{ }^{\circ} \mathrm{C}$ to $400{ }^{\circ} \mathrm{C}$. As for h-AlN(110), no significant change is observed on strain values as annealing temperature increases. Noticeable increase in strain value is observed for c-BN (111) as the annealing temperature increases.

Table III shows the thickness achieved before and after (B, $\mathrm{Al}) \mathrm{N}$ thin films were annealed with different temperature. It can be observed that the thickness of the thin film increased from 78.7 to $113.7 \mathrm{~nm}$ when annealing temperature of $200{ }^{\circ} \mathrm{C}$ was applied. It is found that the thickness decreased from 113.7 to $86.7 \mathrm{~nm}$ as the annealing temperature increased.

TABLE I: STRUCTURAL PROPERTIES OF (B, AL) N THIN FILM ON SI FOR DIFFERENT ANNEALING TEMPERATURES

\begin{tabular}{|c|c|c|c|c|c|c|}
\hline Samples` & Identity & $\begin{array}{l}\text { Observed } 2 \theta \\
\left({ }^{\circ}\right)\end{array}$ & $\begin{array}{l}\text { Standard } 2 \theta \\
\left({ }^{\circ}\right)\end{array}$ & FWHM $\left(^{\circ}\right)$ & $\begin{array}{l}\text { Crystallite } \\
\text { size (nm) }\end{array}$ & $\begin{array}{l}\text { Lattice } \\
\text { parameter } \\
(\AA)\end{array}$ \\
\hline \multirow{3}{*}{$\begin{array}{l}(\mathrm{B}, \mathrm{Al}) \mathrm{N} \text { Non- } \\
\text { annealed }\end{array}$} & h-AlN (100) & 33.159 & 33.216 & 0.118 & 70.18 & 2.700 \\
\hline & h-AlN (110) & 61.834 & 60.004 & 0.072 & 128.57 & 2.120 \\
\hline & c-BN (111) & 43.586 & 43.317 & 0.079 & 108.65 & 8.299 \\
\hline \multirow{4}{*}{$\begin{array}{l}(\mathrm{B}, \mathrm{Al}) \mathrm{N} \\
\text { Annealed } \\
200^{\circ} \mathrm{C}\end{array}$} & h-AlN (100) & 33.142 & 33.216 & 0.039 & 210.52 & 2.701 \\
\hline & h-AlN (002) & 36.005 & 36.041 & 0.472 & 17.68 & 4.984 \\
\hline & h-AlN (110) & 61.768 & 60.004 & 0.098 & 94.044 & 2.123 \\
\hline & c-BN (111) & 43.340 & 43.317 & 0.157 & 54.28 & 3.613 \\
\hline \multirow{3}{*}{$\begin{array}{l}\mathrm{B}, \mathrm{Al}) \mathrm{N} \\
\text { Annealed } \\
300^{\circ} \mathrm{C}\end{array}$} & h-AlN (100) & 33.109 & 33.216 & 0.079 & 105.25 & 2.704 \\
\hline & h-AlN (110) & 61.794 & 60.004 & 0.079 & 117.57 & 2.121 \\
\hline & c-BN (111) & 43.814 & 43.317 & 0.236 & 36.246 & 3.576 \\
\hline \multirow{2}{*}{$\begin{array}{l}(\mathrm{B}, \mathrm{Al}) \mathrm{N} \\
\text { Annealed } \\
400^{\circ} \mathrm{C}\end{array}$} & h-AlN (100) & 33.110 & 33.216 & 0.197 & 42.10 & 2.703 \\
\hline & h-AlN (110) & 61.748 & 60.004 & 0.098 & 94.034 & 2.123 \\
\hline
\end{tabular}

TABLE II. STRUCTURAL PROPERTIES OF (B, Al)N THIN FILM ON SI FOR VARIOUS ANNEALING TEMPERATURES

\begin{tabular}{|c|c|c|c|c|}
\hline Samples & Identity & Internal Stress & $\begin{array}{l}\text { Dislocation } \\
\text { density }\end{array}$ & Strain \\
\hline \multirow{3}{*}{ (B, Al)N Non-annealed } & h-AlN (100) & 0.9064 & $2.03 \times 1014$ & 0.00173 \\
\hline & h-AlN (110) & -14.770 & $6.05 \times 1013$ & 0.00053 \\
\hline & c-BN (111) & -2.0587 & $8.47 \times 1013$ & 0.00086 \\
\hline \multirow{4}{*}{$(\mathrm{B}, \mathrm{Al}) \mathrm{N}$ Annealed $200{ }^{\circ} \mathrm{C}$} & h-AlN (100) & 1.7706 & $2.26 \times 1013$ & 0.00058 \\
\hline & h-AlN (002) & 0.4306 & $3.20 \times 1015$ & 0.00634 \\
\hline & h-AlN (110) & -14.241 & $1.13 \times 1014$ & 0.00072 \\
\hline & $\mathrm{c}-\mathrm{BN}(111)$ & -1.0002 & $3.39 \times 1014$ & 0.00173 \\
\hline \multirow{3}{*}{$(\mathrm{B}, \mathrm{Al}) \mathrm{N}$ Annealed $300^{\circ} \mathrm{C}$} & h-AlN (100) & 1.6910 & $9.03 \times 1013$ & 0.00116 \\
\hline & h-AlN (110) & -14.447 & $7.23 \times 1013$ & 0.00057 \\
\hline & $\mathrm{c}-\mathrm{BN}(111)$ & -21.4998 & $7.61 \times 1014$ & 0.00256 \\
\hline \multirow{2}{*}{$(\mathrm{B}, \mathrm{Al}) \mathrm{N}$ Annealed $400^{\circ} \mathrm{C}$} & h-AlN (100) & 1.6653 & $5.64 \times 1014$ & 0.00289 \\
\hline & h-AlN (110) & -14.077 & $1.13 \times 1014$ & 0.00072 \\
\hline
\end{tabular}




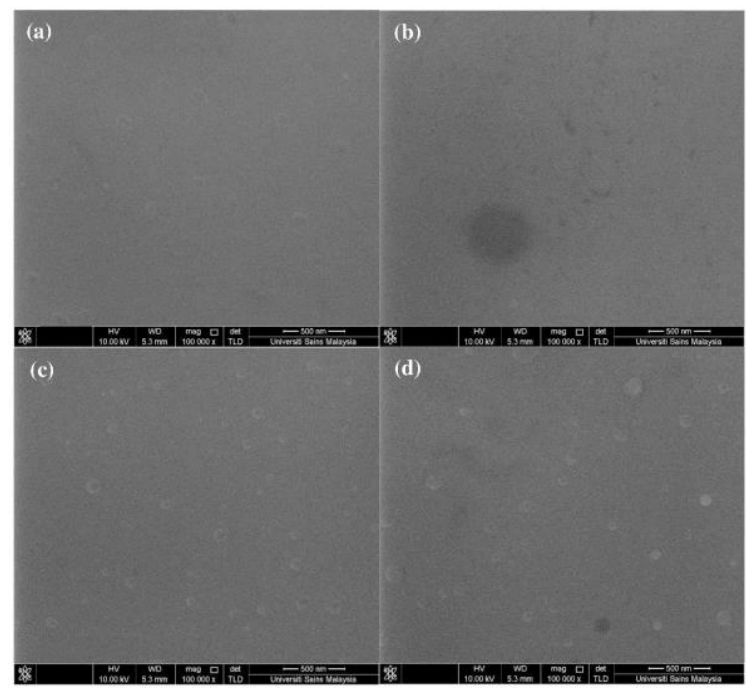

Fig. 2. FESEM images of (B, Al)N thin film surface of (a) Non-annealed, (b) $200{ }^{\circ} \mathrm{C}$, (c) $300{ }^{\circ} \mathrm{C}$ and (d) $400{ }^{\circ} \mathrm{C}$

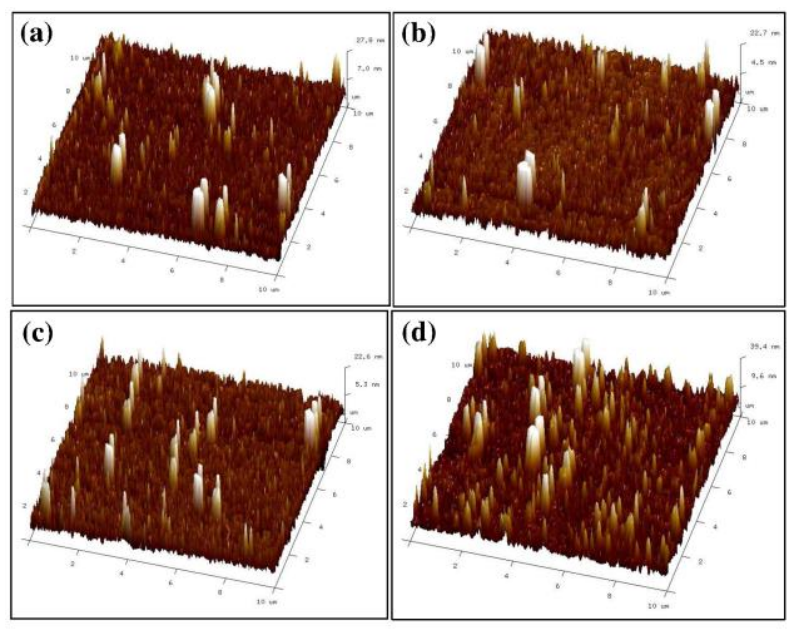

Fig. 3. The AFM images of (B, Al)N thin film surface of (a) Non-annealed, (b) $200^{\circ} \mathrm{C}$, (c) $300^{\circ} \mathrm{C}$ and (d) $400^{\circ} \mathrm{C}$

\subsection{Surface Analysis}

The surface morphology of bare and annealed $(\mathrm{B}, \mathrm{Al}) \mathrm{N}$ thin film is shown in Fig. 2. It clearly shows the distinct images for different annealing temperature. The as-grown sample was smooth and dense nature. Nano pores are observed with $(\mathrm{B}, \mathrm{Al}) \mathrm{N}$ thin film samples when annealed at $200{ }^{\circ} \mathrm{C}$ and also observed the loosely bounded particles. It is also observed that no cluster was found when compared with the samples annealed at $>300{ }^{\circ} \mathrm{C}$. As the annealing temperature increased, the clusters are observed and became obvious as compared with the surface of nonannealed film. The size of irregular clusters increased along with the annealing temperature at $400{ }^{\circ} \mathrm{C}$.

Table IV. Variation of surface roughness, $R a$ at different annealing temperature.

\begin{tabular}{ll}
\hline \hline $\begin{array}{l}\text { Annealing } \\
\text { temperature }\left({ }^{\circ} \mathrm{C}\right)\end{array}$ & Roughness, Ra $(\mathrm{nm})$ \\
\hline Non-annealed & 3.31
\end{tabular}

\begin{tabular}{ll}
200 & 3.25 \\
300 & 3.13 \\
400 & 5.06 \\
\hline
\end{tabular}

Table V. Atomic weight percentage of $(\mathrm{B}, \mathrm{Al}) \mathrm{N}$ at different annealing

\begin{tabular}{llll}
\multicolumn{4}{c}{ temperature } \\
\hline \hline $\begin{array}{l}\text { Annealing } \\
\text { temperature }\left({ }^{\circ} \mathrm{C}\right)\end{array}$ & $\mathrm{B}$ & $\mathrm{Al}$ & $\mathrm{N}$ \\
\cline { 2 - 4 } Weight $(\mathrm{wt} \%)$ \\
\hline Non-annealed & 5.51 & 75.46 & 19.03 \\
$200^{\circ} \mathrm{C}$ & 38.26 & 50.24 & 11.50 \\
$300^{\circ} \mathrm{C}$ & 25.04 & 57.85 & 17.10 \\
$400^{\circ} \mathrm{C}$ & 26.72 & 55.57 & 17.7 \\
\hline \hline
\end{tabular}

From Table V, all the annealed samples show higher weight percentage of boron than the non-annealed sample. It is because of surface diffusion of $\mathrm{Al}$ during the annealing process and hence the $\mathrm{B}$ elements exposed on the top surface of the film. A small decrease in B content could 


\section{International Journal of Engineering Trends and Technology (IJETT) - Volume 17 Number 4 - Nov 2014}

also be noticed with $300{ }^{\circ} \mathrm{C}$ which is due to higher diffusion rate of $\mathrm{B}$ at high annealing temperature. This could be evidenced by observing still higher B content in $400{ }^{\circ} \mathrm{C}$ annealed samples than the samples annealed at 300 ${ }^{\circ} \mathrm{C}$. This will give us the highest percentage of $\mathrm{B}$ in the annealed film than in non-annealed film

\section{CONCLUSIONS}

Co-sputtering was used to deposit B doped AlN thin film on $\mathrm{Si}$ substrates and their structural parameters were evaluated for different annealing temperatures. The formation of hexagonal AlN phase was confirmed along with cubic BN phase for various annealing temperatures by XRD spectra. The structural parameters such as crystallite size, dislocation density, strain, stress were changed with respect to annealing temperatures and revealed the effect of B doping. Boron doping influenced the surface properties of AlN and also the surface elemental composition. Boron inclusion increased the surface roughness of AlN thin film.

\section{ACKNOWLEDGMENT}

This work was financially supported by Collaborative Research in Engineering, Science and Technology (CREST) under grant (304/PFIZIK/650601/C121). The author would also like to thank the lab assistant and staff who is supporting in this work. It is acknowledged for the facilities provided by NOR lab at school of physics for B doped AIN thin film synthesis and characterization

\section{REFERENCES}

[1] J. Chaudhuri, , L. Nyakiti, , R. G. Lee, Z. Gu, J. H.Edgar, and J. G. Wen, Thermal oxidation of single crystalline aluminum nitride. Materials Characterization, Vol. 58, No.8-9, pp. 672-679, 2007

[2] J. Olivares, S. González-Castilla, M.Clement, A. Sanz-Hervás, , L. Vergara, J. Sangrador, and E. Iborra, "Combined assessment of piezoelectric AlN films using X-ray diffraction, infrared absorption and atomic force microscopy," Diamond and Related Materials, Vol. 16, No. 4-7, pp. 1421-1424, 2007

[3] J.P.Kar, G.Bose, and S. Tuli, "A study on the interface and bulk charge density of AlN films with sputtering pressure," Vacuum, Vol. 81, No.4, pp. 494-498, 2006

[4] K.H.Chiu, J.H.Chen, H.R. Chen, and R.S.Huang, "Deposition and characterization of reactive magnetron sputtered aluminum nitride thin films for film bulk acoustic wave resonator," Thin Solid Films, Vol. 515, No. 11, pp. 4819-4825, 2007

[5] V. V. Felmetsger and M. K. Mikhov, "Reactive magnetron sputtering of piezoelectric Cr-doped AlN thin films," 2011 IEEE International Ultrasonics Symposium Proceedings, pp. 835-839, 2011

[6] M. Moreira, J. Bjurstrom, I. Katarjev, and V. Yantchev, "Aluminum scandium nitride thin-film bulk acoustic resonators for wide band applications," Vacuum, Vol. 86, No.1, pp. 23-26, 2011

[7] K. M. Lakin, "Thin film resonators and filters," Ultrasonics Symposium, Proceedings. 1999 IEEE: Vol. 2, pp.895-906. 1999

[8] I. Ivanov, L. Hultman, K. Järrendahl, , P. Mårtensson, , J.-E. Sundgren, , B. Hjörvarsson and J. E.. Greene, "Growth of epitaxial $\operatorname{AlN}(0001)$ on $\mathrm{Si}(111)$ by reactive magnetron sputter deposition," Journal of Applied Physics," Vol.78, pp. 5721-5726, 1995.

[9] R.D. Vispute, V. Talyansky, R.P. Sharma, S. Choopun, M. Downes, T. Venkatesan, Y.X. Li, L.G. Salamanca-Riba, A.A. Iliadis, K.A. Jones and J. McGarrity, "Advanced in pulsed laser deposition of nitrides and their integration of oxides", Applied Surface Science, Vol. 127 - 129, pp 431 - 439, 1998
[10] S. Yoshida, S. Misawa, Y. Fujii, H. Hayakawa, S. Gonda, and A. Itoh, "Reactive molecular beam of epitaxy of aluminium nitride", Journal of Vacuum Science Technology, Vol. 16, (4), pp. 4724 4728, 1995

[11] Gielisse, P.J., Niculescu, H., Xu, Y., Bai, N., \& Tu, M. "Vapor Deposition Equipment and Thin Film Processing". (Report No. AD-A321 245/3), Florida: Florida A\&M University, College of Engineering, http://www.dtic.mil/dtic/tr/fulltext/u2/a321245.pdf, 1996

[12] M. Morita, S. Seiji Isogai, N. Nobuhiro Shimizu, K. Kazuo Tsubouchi, and N. Mikoshiba, "Aluminum Nitride Epitaxially Grown on Silicon: Orientation Relationships," Japanese Journal of Applied Physics, Vol. 20(3), pp. L173-L175. 1982

[13] J.H. Song, J.L. Huang, H.H. Lu, J.C. Sung, "Investigation of wurtzite (B,Al)N films prepared on polycrystalline diamond," Thin Solid Films, Vol. 516, No.2-4, pp. 223-227, 2007

[14] G. Gordillo, J.M. Flrez and L.C. Hernandez, "Preparation and characterization of CdTe thin films deposited by CSS," Solar Energy Materials and Solar Cells, Vol. 37, No. 3-4, pp. 273-281, 1995

[15] J.H. Song, J.L. Huang, H.H. Lu, J.C. Sung, "Investigation of wurtzite (B,Al)N films prepared on polycrystalline diamond," Thin Solid Films, Vol. 516, No.2-4, pp. 223-227, 2007

[16] A. J. Perry, "The state of residual stress in TiN films made by physical vapor deposition methods; the state of the art," Journal of Vacuum Science \& Technology A: Vacuum, Surfaces, and Films, Vol. 8, No. 3, pp. 1351-1358, 1990

[17] D. Gerlich, S. Dole and G. Slack, "Elastic properties of aluminum nitride," Journal of Physics and Chemistry of Solids, Vol. 47, No.5, pp. 437-441, 1986

[18] R. Thokala and J. Chaudhuri, "Calculated elastic constants of wide band gap semiconductor thin films with a hexagonal crystal structure for stress problems," Thin Solid Films, Vol. 266, No.2, pp.189-191, 1995

[19] Boron Nitride, Mechanical Properties, Elastic Constants, Lattice Vibrations. New Semiconductor Materials Archive. Retrieved August 13, 2014, from Electronic Archive, New Semiconductor Materials Archive website: http://www.ioffe.ru/SVA/NSM/Semicond/BN/mechanic.html

[20] A. R. Stokes and A. C. J Wilson, "The diffraction of X rays by distorted crystal aggregates - I," Proceedings of the Physical Society: Vol. 56, pp. 174, 1944

[21] G. Este, and W.D. Westwood, "Stress control in reactively sputtered AlN and TiN films," Journal of Vacuum Science \& Technology A, Vol. 5, pp. 1892-1897, 1987

[22] Bunshah , R. F. (2001). Handbook of hard coatings. USA: Noyes Publication.

[23] G. T. Du, J.Z. Wang, X.Q. Wang, X.Y. Jiang, S.R. Yang, Y. Ma, W. Yan, D.S. Gao, X. Liu, H. Cao, J.Y. Xu, and R.P.H. Chang, "Influence of annealing on $\mathrm{ZnO}$ thin film grown by plasma-assisted MOCVD," Vacuum, Vol. 69, No.4, pp. 473-476, 2003. 